\title{
Pendidikan Multikultural Berbasis Afektif Sufistik bagi Pembentukan Karakter
}

\section{Ideal Siswa}

\section{Pariyati}

\author{
SMP N 1 Pegandon Kendal
}

Pariyati1972@gmail.com

\begin{abstract}
The concept of Islamic religious education such as kalam and fiqih is more directed towards the development of affective capable of experiencing multicultural realities, so that the spirit of Sufi teachings that develop multicultural morality through two things: the first "al sidq ma'a Allah" (honest with God), second "Husn al mu'amalah ma'a al nas" (behave well with fellow human beings). This research includes the type of library research (library research) with the analysis used is descriptive analytical. The role of Sufistic-Based Multicultural Multicultural Education for Student Character Building lies in the learning process that emphasizes intellectual intelligence, emotional and spiritual intelligence in every process undertaken by emphasizing appreciation of the individual's individuality of the students and promoting affection in teaching students as parents to their natural children, there is no favoritism in giving treatment to every student, all students are treated and educated according to their ability and emphasized to mutual respect difference with other friend, so in the end student will have akhlakul karimah as nature of Allah SWT in everyday life with emphasize at power qalb on student self.
\end{abstract}

Keywords: Education, sufi, affection.

\section{Intisari}

Konsep pendidikan agama Islam seperti kalam dan fiqih lebih diarahkan pada pengembangan afektif yang mampu merasakan berbagai realitas yang bersifat multicultural, sehingga semangat ajaran sufistik yang mengembangkan moralitas multikultural melalui dua hal: pertama "al sidq ma'a Allah" (jujur bersama Allah), kedua "husn al mu'amalah ma'a al nas" (berperilaku baik dengan sesama manusia).Penelitian ini termasuk jenis penelitian kepustakaan (library research) dengan analisis yang digunakan adalah deskriptif analitis. Peran Pendidikan Multikultural Berbasis Afektif Sufistik bagi Pembentukan Karakter Siswa terletak pada proses pembelajaran yang mengedepankan kecerdasan intelektual, kecerdasan emosional dan spiritual dalam setiap proses yang dilakukan dengan menekankan pada penghargaan terhadap keberagamaan setiap individu siswa dan mengedepankan kasih sayang dalam mengajar siswa sebagaimana orang tua terhadap anak kandungnya, tidak ada pilih kasih dalam memberikan perlakuan kepada setiap siswa, semua siswa diperlakukan dan dididik sesuai kemampuannya dan ditekankan untuk saling menghargai perbedaan dengan teman lainnya, sehingga pada akhirnya siswa akan memiliki akhlakul karimah sebagaimana sifat Allah SWT dalam kehidupan sehari-hari dengan menekankan pada kekuatan qalb pada diri siswa.

Kata Kunci: Pendidikan, sufistik, kasih sayang. 


\section{Pendahuluan}

Pendidikan yang selama ini diwacanakan di berbagai aktivitas itu adalah pendidikan pada taraf teoritik.Pendidikan yang sebenarnya adalah pendidikan yang mampu mengenal, mampu mengakomodir segala kemungkinan, memahami heterogenitas, menghargai perbedaan baik suku, bangsa, terlebih lagi agama (Dawam, 2003: 8788).Berbagai kerusuhan masalah karena perbedaan suku, agama, ras, terjadi di Indonesia, kerusuhan di Ambon, sampit karena dipicu perbedaan agama, atau bahkan sesama agama bertengkar karena beda pemahaman seperti Aksi penyerangan terhadap pengikut Syi'ah terjadi di Dusun Nangkernang, Desa Karang Gayam, Kecamatan Omben, Kabupaten Sampang, Madura, Jawa Timur pada Agustus 2012 silam. Sebanyak dua orang warga Syi'ah tewas dan enam orang lainnya mengalami luka berat serta puluhan warga mengalami luka ringan. Kasus ini sebenarnya sudah berlangsung sejak tahun 2004.Klimaksnya adalah aksi pembakaran rumah ketua Ikatan Jamaah Ahl al-Bait (IJABI), Tajul Muluk, beserta dua rumah jamaah Syi'ah lainnya serta sebuah musala yang digunakan sebagai sarana peribadatan. Aksi tersebut dilakukan oleh sekira 500 orang yang mengklaim diri sebagai pengikut ahlus sunnah wal jama'ah (http://news.okezone.com, 2 Maret 2018).

Fokus utama pendidikan diletakkan pada tumbuhnya kesadaran kepintaran anak yaitu kepribadian yang sadar diri, kesadaran budi sebagai pangkal dari kesadaran kreatif.Dari akar dan kepribadian yang sadar diri atau suatu kualitas budi luhur inilah manusia bisa berkembang mandiri di tengah lingkungan sosial yang terus berubah semakin cepat.Kualitas pribadi yang pintar dasar orientasi pendidikan kecerdasan, kebangsaan demokrasi dan kemanusiaan, ide ini seharusnya nampak lebih jelas dalam pendidikan(Mulkhan, 2002: 71).Pendidikan iman atau tauhid, bukan sekedar menghafalkan nama-nama tuhan, malaikat, nabi atau rasul.Inti pendidikan keagamaan ialah penyadaran diri tentang hidup dan kematian,bagi tumbuhnya kesadaran ketuhanan.Dari kesadaran seperti ini bisa dibangun komitmen ritualitas, ibadah, hubungan sosial berdasar harmonis dan ahklak sosial yang karimah(Mulkhan, 2002: 72).

Penyelenggaraan pendidikan multikultural di dunia pendidikan diyakini dapat menjadi solusi nyata bagi konflik dan disharmonisasi yang terjadi di masyarakat, khususnya yang kerap terjadi di masyarakat Indonesia yang secara realitas 
plural.Dengan kata lain, pendidikan multikultural dapat menjadi sarana alternatif pemecahan konflik sosial budaya. Al Qur'an memandang pendidikan merupakan sesuatu yang sangat inti dalam kehidupan.Disamping itu, pendidikan juga merupakan hal yang penting bagi setiap individu dan masyarakat.Pentingnya pendidikan ini tidak hanya terbatas kepada suatu umat, bangsa, masyarakat atau pada masa tertentu, tetapi pendidikan mencakup seluruh umat dan masyarakat Islam dewasa ini (Muhammad,2003:60-61).

Mengingat pentingnya pendidikan tersebut, maka dunia sufistik menawarkan konsep pendidikan multikultural berbasis afektif (rasa) dengan karakteristik pada pengembangan paradigma keberagaman yang inklusif.Pengembangan kesadaran untuk dapat belajar hidup dalam perbedaan, penanaman, sikap toleran, cinta keharmonisan, kebaikan, dan kemaslahatan, saling menghargai, menghormati dan saling menyayangi.Hasil yang diharapkan dari pendidikan tersebut adalah kemampuan kognitif yang disertai rasa mahabbah (cinta) kepada Allah dan Rasul-Nya.Karena potensi mahabbah ini dalam pandangan psikologi sufistik dapat membentuk perilaku psikologis yang konstruktif, baik dalam ucapan, perbuatan, sikap, persepsi maupun pemikiran (Muhammad,2003:60-61).

Pendidikan berbasis tingkah laku afektif yang bernuansa multikultural tersebut, secara substansial sejalan dengan semangat ajaran sufistik yang mengembangkan moralitas multikultural melalui dua hal: pertama "al sidq ma'a Allah" (jujur bersama Allah), kedua "husn al mu'amalah ma'a al nas" (berperilaku baik dengan sesama manusia), sehingga Hasil yang diharapkan dari pengembangan pendidikan multikultural tersebut adalah terwujudnya output yang shalih, berakhlak mulia kepada Allah, kepada sesama manusia dan kepada makhluk Allah yang lainnya. Hal ini selain sejalan dengan landasan aksiologi psikologi sufistik yang menaruh perhatian pada nilai-nilai moral, juga sesuai dengan spirit ajaran sufistik yang lebih mengutamakan akhlak mulia (Muhammad,2003:60-61).

Dengan model pembekalan keilmuan tersebut, anak didik diharapkan memiliki keseimbangan kemampuan kognitif, afektif dan psikomotorik yang berdampak positif bagi kedewasaan karakter, sehingga mampu memahami realitas hidup dalam keberbedaan, saling menghargai dan menghormati, serta saling mencintai kedamaian dan keharmonisan. Konsep ini dapat diaktualisasikan, manakala proses pembelajaran 
menekankan integrasi pengembangan pemahaman kognitif dalam tataran formalitas normatif, dan pengembangan afektif yang dapat merespon terhadap substansi ajar, untuk kesempurnaan moral (Hadziq, 2008: 451-452). Berdasarkan latar belakang tersebut, maka rumusan dalam penelitian ini adalah bagaimana bagaimana peran pendidikan multikultural berbasis afektif sufistik bagi pembentukan karakter siswa?

\section{Metode Penelitian}

Dalampenyusunan makalah ini penulis menggunakan metode penulisan kepustakaan (library research) (Zed, 2004: 5).Maka penulis menggunakan teknik yang diperoleh dari perpustakaan dan dikumpulkan dari buku-buku tersebut yaitu hasil membaca dan mencatat dari buku ilmiah yang berkaitan dengan pembahasan dan permasalahannya.

Analisis yang digunakan adalah deskriptif analitis.Metode deskriptif analitisakandigunakan dalam usaha mencari dan mengumpulkan data, menyusun, menggunakan serta menafsirkan data yang sudah ada (Mas'ud, 2002: 19).Untuk menguraikan secara lengkap, teratur dan teliti terhadap suatu obyek penulisan (Sudarto, 2001: 116), yaitu menguraikan dan menjelaskanpendidikanmultikultural berbasis afektif sufistik bagi pembentukan karakter siswa yang ideal.

\section{Pembahasan}

Psikologi sufistik dengan pendekatan afektif memiliki peluang untuk memberikan kontribusi bagi pengembangan pendidikan multikultural yang ada di Indonesia.Bentuk kontribusinya adalah konsep pendidikan multikultural berbasis tingkah laku afektif, dengan model pembelajaran yang menghasilkan keseimbangan kemampuan fikir, kecerdasan rasa dan kemuliaan budi pekerti atas dasar norma-norma etis kemanusiaan dan nilai-nilai ketuhanan dalam tataran keduniaan dan keakhiratan. Hasil pembelajaran yang diharapkan adalah subjek didik yang mampu memahami akan citra dirinya dalam keterkaitannya dengan Tuhan, mampu merasakan perasaan orang lain, mampu menerima perbedaan dan persamaan antar berbagai ragam pendapat, etnis, budaya, agama dan politik, serta mencintai nilai-nilai kebersamaan kedamaian.

Tujuan pendidikan ialah orientasi yang dipilih pendidik dalam membimbing peserta didiknya. Pemilihan merupakan proses penilaian. Karenanya, manakala pendidikan telah menentukan pilihannya, sesungguhnya ia telah mengutamakan 
sebagian nilai atas sebagian yang lain. Dengan demikian, tujuan pendidikan berkaitan dengan nilai-nilai yang dijunjung tinggi oleh pendidik di dalam hidupnya.

Nilai di atas, memiliki dua dimensi; intelektual dan emosional. Kombinasi dua dimensi ini menentukan suatu nilai yang disebut norma atau prinsip (Kaswardi, 1993: 24-25). Ada beberapa nilai yang menjadi dasar penetapan tujuan pendidikan. Nilai tersebut meliputi: (1) nilai material yaitu memelihara keberadaan manusia dari segi materi, (2) nilai sosial yang lahir dari kebutuhan manusia untuk interaksi dengan sesamanya, (3) nilai intelektual yang berkaitan dengan kebenaran dan pencarian ilmu, (4) nilai etis yang menjadi sumber kewajiban dan tanggungjawab. Selain di atas, ada pula nilai religius dan spiritual yang menghubungkan manusia dan penciptanya.

Pendidikan multicultural memberikan gambaran bagaimana memberikan pola pendidikan karakter pada anak didik dengan menekankan pada keragaman karakter peserta didik perlu dibina sesuai dengan potensi masing-masing-masing dengan menekankan pada humanisme. Tidak mengadili siswa namun mengarah pada proses menyayangi. Paradigma pendidikan multikultural, yakni: Pertama, pendidikan multikultural merupakan sebuah proses pengembangan. Pengembangan disini lebih dimaknai sebagai sebuah proses, sebab tidak dibatasi oleh ruang dan waktu, subjek, objek dan relasinya. Proses ini dapat dilakukan kapan, dimana dan oleh siapa saja. Kedua, Pendidikan Multikultural adalah mengembangkan seluruh potensi manusia.Potensi-potensi yang dimiliki pada hakikatnya adalah sebuah anugerah yang harus dikembangkan berdasarkan pada nila-nilai fitrah kemanusiaannya.Selain itu pendidikan multikultural diarahkan untuk mengembangkan pribadi-pribadi manusia Indonesia agar menjadi manusia-manusia yang cerdas.Ketiga, pendidikan mulrikultural adalah pendidikan yang menghargai pluralitas.Seperti yang sudah penulis ungkap dalam orientasi pendidikan multikultural bahwa pendidikan multikultural adalah pendidikan yang menghargai pluralitas karena pluralitas adalah sunatullah.Keempat, Pendidikan multikultural adalah pendidikan yang menjunjung tinggi keragaman budaya, adat, suku, agama.Dengan melihat keragaman yang ada maka sikap menghormati dan menghargai bahkan menjunjung tinggi harkat dan martabat semua orang adalah sikap yang sangat penting.

Melalui pola pendidikan tersebut setiap peserta didik akan mampu melaksanakan proses pendidikan sesuai dasar kemanusiannya dan 
ditumbuhkembangkan sesuai kemampuannya masing-masing.Konflik yang banyak terjadi di Indonesia membuktikan telah terjadi missing link antara pendidikan agama dengan pendidikan nilai. Oleh karena itu perlu adanya penambahan kurikulum pendidikan islam yang sifatnya universal, nilai humaniora (kemanusiaan). Penambahan nilai-nilai universal dalam pendidikan bukan berarti ingin menonjolkan sifat-sifat liberal. Pendidikan Islam namun dimaksudkan dengan pemahaman dengan nilai-nilai universal anak didik akan dapat mengejawantahkan nilai-nilai tersebut dalam kehidupan bermasyarakat.

Kemanusiaan menjadi agenda penting dalam proses pendidikan. Karena pendidikan tidak saja berkaitan transfer pengetahuan yang sifatnya keilmuan namun ada sisi lain yang lebih penting dari pendidikan yaitu suatu proses internalisasi nilai kepada anak didik. Oleh karena itu focus pendidikan tidak hanya terletak pada aspek kognitif semata, namun aspek afeksi dan psikomotor menjadi agenda penting yang tidak dapat dikesampingkan. Manusia sebagai makhluk social yang tidak dapat hidup tanpa dan dengan orang lain.

Ruang kelas bagaikan penjara tanpa peluang kreatif dan inovatif, hal ini terlihat dari tujuan pendidikan "membentuk kepribadian muslim berakhlak mulia" dan seterusnya.Tujuan ini diberlakukan untuk semua jenis, jenjang, bidang studi. Pendidikan hanyalah keinginan atasan (guru dan para elit penguasa) bukan sebaliknya pendidikan untuk membimbing dan mendampingi peserta didik dengan segala problem kehidupan dan keadaan masyarakat di mana ia berada.

Siswa sebagai layaknya manusia mempunyai kebebasan mengekspresikan potensi yang dimilikinya.Berpikir kritis, inovatif serta kreatif, namun justru potensi ini dipasang di lembaga pendidikan.Kekerasan sistematik di ruang kelas mengisyaratkan kemanusiaan belum diperhatikan, siswa dianggap mesin foto copy yang harus mengikuti kemauan atasan dan materi pendidikan agama berupa instan yang datang dari penguasa. Meletakkan siswa pada obyek pendidikan bukan pada subyek pendidikan dengan sendiri akan mematikan potensi manusia yang secara kodrati berpotensi untuk berkembang. Dengan begitu peran sekolah berubah fungsi melakukan pendampingan berubah fungsi melakukan pendampingan kepada peserta didik tetapi lebih pada menciptakan manusia-manusia mesin/robot.Kalau model pembelajaran seperti itu maka penciptaan manusia Indonesia yang seutuhnya (insan kamil) hanya utopia belaka. 
Membiasakan anak didik untuk berpikir kritis, analisis, inovatif dan kreatif.Mendialogkan pengetahuan yang didapat di bangku sekolah dengan realitas empiris masyarakat. Sehingga dengan demikian akan terjadi proses perenungan antara pengetahuan yang dimilikinya dengan realitas sosial akan memungkinkan siswa tumbuh dengan penghormatan atas pluralitas yang unik. Dengan demikian akan terus mendialogkan pengetahuan dengan perkembangan zaman.Karena pada dasarnya hamba yang saleh adalah orang-orang yang baik, unggul dan mampu berbuat baik terhadap sesama serta memperbaiki lingkungan sekitar, kesalehan pribadi berarti meningkatkan keimanan dan partisipatoris yang dilandasi tingginya iman dan takwa terhadap Allah SWT.

Psikologi sufistik menawarkan konsep pendidikan multikultural berbasis afektif, dengan karakteristik pada pengembangan pradigma keberagaman yang inklusif, pengembangan kesadaran untuk dapat belajar hidup dalam perbedaan, penanaman sikap toleran, cinta keharmonisan, kebaikan dan kemaslahatan, saling menghargai, menghormat dan saling menyayangi.Pendidikan adalah pendidikan yang lebih menekankan pendidikan intelektual, emosional dan spiritual, pengembangan kecerdasan emosional dan spiritual kurang, seharusnya ketiga kecerdasan tersebut atau meta kecerdasan diterapkan dalam pendidikan sehingga akan melahirkan anak bangsa yang baik, positif, baik, sholeh dan sholihah.

Seorang individu mempunyai tanggung jawab dengan Tuhan atas tindakannya serta bertanggung jawab secara moral dengan masyarakat (sosial), dan alam semesta.Jadi adanya upaya memadukan kesalehan personal dan kesalehan sosial, keselamatan insaniyah, kemaslahatan basyariyah, serta keselamatan alam.Pendidikan tidak semata memicu kecerdasan yang bersifat kognitif semata, tetapi juga aspek afektif dan psikomotorik yaitu, perilaku konkrit terhadap sosial kemasyarakatan (Attas, 2004: 189).Suatu dialog dalam pendidikan sosial harus selalu mengandalkan kerendahan hati untuk membandingkan konsep-konsep ideal yang dimiliki agama lain yang hendak dibandingkan, dan realitas agama, baik yang agung atau yang memalukan dengan realitas agama lain yang kemajuan manusia, ketika ia menerima orang dan berkoeksistensi bersamanya, dan ketika telah matang ia akan melihat sisi elemen dan sifat-sifat akhlak serta factor-faktor dan sifat-sifat kesatuan dan kesamaan. Ketika kematangan itu mencapai batas yang dapat melihat keniscayaan perbedaan pendapat 
sebagaimana halnya kesamaan pendapat karena kemajemukan, pluralitas adalah hiasan kehidupan dan membantu orang-orang yang hidup.Ia adalah fitrah manusia, dan bagian penting dari beragam sisi primer kehidupan.Pendidikan berbasis tingkah laku afektif yang bernuansa multikultural tersebut, secara substansial sejalan dengan semangat ajaran sufistik yang mengembangkan moralitas multikultural melalui dua hal: pertama "al sidq ma'a Allah" (jujur bersama Allah), kedua "husn al mu'amalah ma'a al nas" (berperilaku baik dengan sesama manusia) (Attas, 2004: 189).

Jika potensi-potensi psikologis tersebut berada dalam posisi netral / stabil, maka akan mampu menghasilkan optimalisasi fungsi kerja god spot yang selalu mendorong ke arah kesadaran bertingkah laku positif yang bernuansa multicultural (Hadziq, 2012: 42).Baik buruknya tingkah laku psikologis, ditentukan oleh keadaan potensi batin (inner potensial).Dengan demikian, potensi batin (faktor intern) memiliki hubungan yang signifikan dengan tingkah laku psikologis. Temuan ini termasuk unik, karena memiliki kekhususan dibanding dengan pemikiran psikologis modern.Kekhususan ini terlihat pada pemikiran tentang faktor batin intern manusia, selain bersifat positif juga sebagai penentu utama bagi tingkah laku psikologisnya. Jika potensi batin dikembangkan secara maksimal, maka akan berpengaruh positif terhadap tingkah laku, sebaliknya, bila potensi batin ini ditekan atau dibiarkan terus tanpa adanya upaya pengembangan, maka akan berpengaruh negatif pula terhadap tingkah laku seseorang (Hadziq, 2005: 229).

Konsep pendidikan yang bernuansa multikultural lebih diarahkan pada pengembangan afektif yang mampu merasakan berbagai realitas yang bersifat multikultural, seperti pengembangan: (1) sikap toleran, empati dan simpati terhadap orang lain, (2) sikap mencintai nilai-nilai kebersamaan dan keharmonisan, (3) nilai-nilai yang berpengaruh terhadap kedewasaan emosional, (4) sikap atas pengakuan terhadap kehadiran etnis, kelompok, budaya, agama, atau aliran paham lain, (5) sikap saling percaya satu dengan yang lain, (6) sikap setia untuk menerima perbedaan dan persamaan antar berbagai ragam pemikiran, pandangan dan pendapat, serta (7) sikap apresiasi terhadap tatanan sosial yang plural (Hadziq, 2007: 453).

Hal yang terpenting dalam penciptaan karakter siswa adalah guru tidak boleh menjustifikasi kesalahan orang karena hukum formal, namun kepada pendekatan multicultural yang berangkat dari sebab, sebagaimana dicontohkan oleh sahabat Umar RA ketika ada seseorang yang mencuri, seharusnya secara hukum formal dipotong 
tangan, namun ketika Umar RA mengetahui latar belakang yang mencuri karena kebutuhan yang mendesak dan kemiskinan yang dideritanya, makanya tidak jadi dihukum dimaafkan.

Pembentukan karakter siswa juga perlu ditekankan pada qalb itu sangat menentukan tingkah-tingkah lahiriyah seseorang, sedangkan di barat akal menentukan tingkah laku seseorang. Pandangan sufistik mengarah pada perilaku seseorang ditentukan qalb dan qalb mampu menentukan baik buruknya seseorang sehingga seseorang akan menjadi orang baik jika baik qalbnya bukan otaknya dan kecerdasan yang dimilikinya adalah kecerdasan hakiki yang tidak hanya pintar menilai tapi juga pintar merasakan, tidak hanya mengetahui mudharat mencuri dan korupsi namun tertanam dalam dirinya untuk tidak melakukan pencurian dan korupsi atau perbuatan tidak terpuji lainnya, juga memiliki jiwa kasih sayang dalam kehidupannya dan memandang seseorang dengan kegembiraan dan positif.Qalb disamping mengemban fungsi kognisi dan emosi, ia juga mengemban fungsi spititual. Hal ini tidak lain, karena qalb merupakan tempat akidah, disanalah ia bersemayam, tumbuh, berkembang sesuai dengan sarana pengembangan, peningkatan dan penguatan yang diupayakan oleh manusia didalamnya. Hubungan akidah dengan qalb adalah sebagai hal-hal yang dibenarkan dalam hati, menentramkan jiwa, menjadi keyakinan dalam diri seseorang, tidak tercampuri dengan kebimbangan maupun keraguan sedikitpun. Dalam pandangan tasawuf hati (qalb) mempunyai beberapa fungsi yang sangat penting antara lain:

1. Sebagai alat untuk menemukan penghayatan ma 'rifah kepada Allah.

2. Hati berfungsi untuk beramal hanya kepada Allah, sedangkan anggota badan lainnya hanyalah alat yang dipergunakan oleh hati.

3. Hati pula yang taat pada Allah, adapun gerak ibadah semua anggota badan adalah pancaran hatinya (Solihin dan Anwar, 2002: 166-167).

Menurut Ma'an az-Ziyadah seperti yang dikutip oleh Jusuf Mudzakir, memberikan argumennya bahwa qalb berfungsi sebagai alat untuk menangkap hal-hal yang doktriner (al-i'tiqodiyah), memperoleh hidayah, ketakwaan, dan rahmah, serta mampu memikirkan dan merenungkan sesuatu (Mujib dan Mudzakir, 2001: 327).

Potensi nafs yang ditumbuhkembangkan ke arah pencapaian ketenangan batin, akan dapat dijadikan sebagai media pengembangan tingkah laku yang lebih bermoral dan beradab. Kemungkinan ini dapat dibenarkan, karena potensi jiwa yang amat sehat 
(tenang) cenderung memihak kepada nilai-nilai luhur dan tingkah laku terpuji atas dasar pertimbangan hati nurani dan akal sehat yang pada akhirnya tertanam pada diri seseorang tersebut rasa kasih sayang terhadap sesama dan menghargai perbedaan dengan penuh penghormatan dan kasih sayang.Setelah manusia sampai pada tahapan etis dan religius, secara psikologi muncullah kesadaran dari dalam dirinya untuk menghargai norma-norma etis dan keinginan untuk berhubungan dengan adikodrati. Dalam istilah sufistik disebut sebagai keinginan untuk selalu taqorrub ila Allah. Untuk memenuhi kebutuhan akan kesadaran psikologis tersebut, maka pendidikan multicultural yang masih sekuler perlu diintegrasikan dengan pendidikan afektif yang bermuatan moral multikultural dalam bingkai sufistik (Hadziq, 2016: 18).

Implikasi pendidikan multikultural berbasis afektif sufistik pengembangan karakter siswa ideal telah menjadi tugas seorang guru dan ini tidak hanya menjadi tugas pendidik agama Islam tapi juga pendidik mata pelajaran lain, karena pendidikan karakter yang mengarah pada multikultural berbasis afektif sufistik juga bisa didekati dengan mata pelajaran seperti pelajaran kimia, matematika atau pendidikan lain dengan mengaitkan mata materi itu dengan kajian multikultural berbasis afektif sufistik. Ada beberapa nilai yang dapat dikembangkan dalam pendidikan multikultural berbasis afektif sufistik dalam rangka mengelola karakter siswa diantaranya: nilai keimanan, nilai keikhlasan, nilai kesabaran, nilai syukur, nilai keadilan, nilai kedermawanan dan nilai pemaafan.

Upaya pendidikan atau pembentukan karakter yang mengarah kepada jalan pembersihan diri dari sifat-sifat tercela (takhalli), kemudian mengisi diri dari sifat-sifat terpuji (tahalli), yang dilanjutkan dengan pemahaman dan pengamalan secara tulus (tajalli) sebagai pangkal dari ajaran tasawuf merupakan alternatif dari terapi Islam dalam memecahkan segala persoalan hidup manusia khususnya pada siswa.Pendidikan multikultural berbasis afektif sufistik pengembangan karakter siswa mengedepankan Humanisme.Humanisme dimaknai sebagai potensi (kekuatan) individu untuk mengukur dan mencapai ranah ketuhanan serta mampu menyelesaikan persoalan-persoalan sosial. Sementara itu, pendidikan islam merupakan suatu proses dalam pembentukan manusia sesuai dengan cita-cita Islam. Dengan demikian, humanisme dalam dunia pendidikan Islam merupakan proses pendidikan yang lebih memperhatikan aspek potensi manusia 
sebagai makhluk berketuhanan dan makhluk berkemanusiaan serta individu yang diberi kesempatan oleh Allah untuk mengembangkan potensi-potensinya (Mas'ud,2002:135).

Hal ini sejalur dengan apa yang dinamakan Freire sebagai konsep "praxis” yaitu "rangkaian kegiatan pendidikan yang diberikan kepada orang agar mau dan mampu mengambil sikap dan melakukan perbuatan, setelah ia mengadakan pengukuran dan penilaian terhadap dirinya sendiri (reflective thinking)"'(Sarwoko, t.th.:23).Dengan aksi dan refleksi otentik inilah manusia bisa melakukan transformasi realitas yang menindas, mendominasi dan dehumanis menuju pembebasan serta humanisasi.Misalnya pendidikan kebersihan dalam Islam, seharusnya tidaklah hanya dengan menggunakan pesan-pesan melalui tulisan "Bersih pangkal sehat" atau "An-Nadzofatu minal imaan", tetapi yang jauh lebih penting adalah penerapan dari pesan-pesan tersebut dalam kehidupan sehari-hari. Lebih lanjut Abdullah Hadziq d menjelaskan tentang beberapa prinsip dalam rangka melaksanakan konsep di atas (reward dan punishment) secara seimbang, antara lain: "pertama, kesabaran, keuletan dan ketegarannya dalam menegakkan ajaran Islam. Kedua, pemaaf, tanpa dendam dan dengki kepada orang lain yang berbuat salah kepadanya. Ketiga, Mencintai dan menyayangi sesama mukmin.”

Jadi peran Pendidikan Multikultural Berbasis Afektif Sufistik bagi Pembentukan Karakter Siswa terletak pada proses pembelajaran yang mengedepankan kecerdasan intelektual, kecerdasan emosional dan spiritual dalam setiap proses yang dilakukan dengan menekankan pada penghargaan terhadap keberagamaan setiap individu siswa dan mengedepankan kasih sayang dalam mengajar siswa sebagaimana orang tua terhadap anak kandungnya, tidak ada pilih kasih dalam memberikan perlakuan kepada setiap siswa, semua siswa diperlakukan dan dididik sesuai kemampuannya dan ditekankan untuk saling menghargai perbedaan dengan teman lainnya. Pembentukan karakter yang dikembangkan melalui pendidikan multikultural berbasis afektif sufistik yang terpenting adalah mengembangkan nilai-nilai asmaul husna dalam kepribadian dan perilaku siswa sesuai dengan kapasitas kemampuan kemanusiannya sehingga pada akhirnya siswa akan memiliki akhlakul karimah sebagaimana sifat Allah SWT dalam kehidupan sehari-hari dengan menekankan pada kekuatan qalb pada diri siswa. 


\section{Simpulan}

Berdasarkanuraian di atas dapat disimpulkan bahwa peran Pendidikan Multikultural Berbasis Afektif Sufistik bagi Pembentukan Karakter Siswa terletak pada proses pembelajaran yang mengedepankan kecerdasan intelektual, kecerdasan emosional dan spiritual dalam setiap proses yang dilakukan dengan menekankan pada penghargaan terhadap keberagamaan setiap individu siswa dan mengedepankan kasih sayang dalam mengajar siswa sebagaimana orang tua terhadap anak kandungnya, tidak ada pilih kasih dalam memberikan perlakuan kepada setiap siswa, semua siswa diperlakukan dan dididik sesuai kemampuannya dan ditekankan untuk saling menghargai perbedaan dengan teman lainnya. Pembentukan karakter yang dikembangkan melalui pendidikan multikultural berbasis afektif sufistik yang terpenting adalah mengembangkan nilai-nilai asmaul husna dalam kepribadian dan perilaku siswa sesuai dengan kapasitas kemampuan kemanusiannya sehingga pada akhirnya siswa akan memiliki akhlakul karimah sebagaimana sifat Allah SWT dalam kehidupan sehari-hari dengan menekankan pada kekuatan qalb pada diri siswa.

\section{Daftar Pustaka}

Attas, M. Naqub Al, 2004, Filsafat dan Praktik Pendidikan dalam Islam, Bandung: Mizan

Dawam, Ainurrafiq, 2003, Emoh Sekolah "Menolak komersialisasi pendidikan dan Kanibalisme Intelektual menuju Pendidikan Multikultural”, Yogyakarta: Inspeal Prees

Hadziq, Abdullah, 2005, Rekonsiliasi Psikologi Sufistik dan Humanistik, Semarang: RaSAIL

---------, 2007, Psikologi Sufistik: Upaya Menawarkan Solusi Pengembangan Pendidikan Multicultural, Semarang: Institut Agama Islam Negeri Walisongo

--------, 2008, "Psikologi Sufistik: Solusi Pengembangan Pendidikan Multikultural", Teologia, Volume 19, Nomor 2 Juli

--------, 2012, Meta Kecerdasan \& Kesadaran Multikultural Kajian Pemikiran Psikologi Sufistik Al-Ghazali, Semarang: t.p.

--------, 2016, AMANAT UIN Walisongo Semarang, Edisi 126, September

Kaswardi, E.M.K. (ed.), 1993, Pendidikan Nilai Memasuki Tahun 2000, Jakarta: Gramedia

Mas'ud, Abdurrahman, 2002, Dikotomi Ilmu Agama dan Non Agama, Semarang: IAIN Walisongo 
2002, Menggagas Format Pendidikan Nondikotomik; Humanisme Religius Sebagai Paradigma Pendidikan Islam, Yogyakarta: Gama Media

Muhammad AR, 2003, Pendidikan di alaf baru"Rekonstruksi atas moralitas pendidikan" Jogyakarta: Prismashophie

Mujib, Abdul dan Jusuf Mudzakir, 2001, Nuansa-Nuansa Psikologi Islam, Jakarta: PT Raja Grafindo Persada

Mulkhan, Abdul Munir, 2002, Nalar Spiritual Pendidikan Islam Solusi Problem Filosofis Pendidikan Islam, Yogyakarta: PT Tiara Wacana Yogya

Sarwoko, Bambang, t.th.,Konsep Dasar Pendidikan Luar Sekolah, Semarang: IKIP Semarang Press

Solihin, M. dan Rosihan Anwar, 2 2 us Tasawuf, Bandung: PT Remaja Rodakarya

Sudarto, 2001, Metode Penulisan Filsafat, Jakarta: Rajawali Press

Zed, Mestika, 2004, Metode Penulisan Kepustakaan, Jakarta: Yayasan Obor Indonesia

http://news.okezone.com/read/2016/02/25/340/1320731/lima-konflik-sara-palingmengerikan-ini-pernah-terjadi-di-indonesia?page $=2$ 